\title{
A test on Ellenberg indicator values in the Mediterranean evergreen woods (Quercetea ilicis)
}

\section{Corrado Marcenò \& Riccardo Guarino}

\section{Rendiconti Lincei}

SCIENZE FISICHE E NATURALI

ISSN 2037-4631

Volume 26

Number 3

Rend. Fis. Acc. Lincei (2015) 26:345-356

DOI 10.1007/s12210-015-0448-8

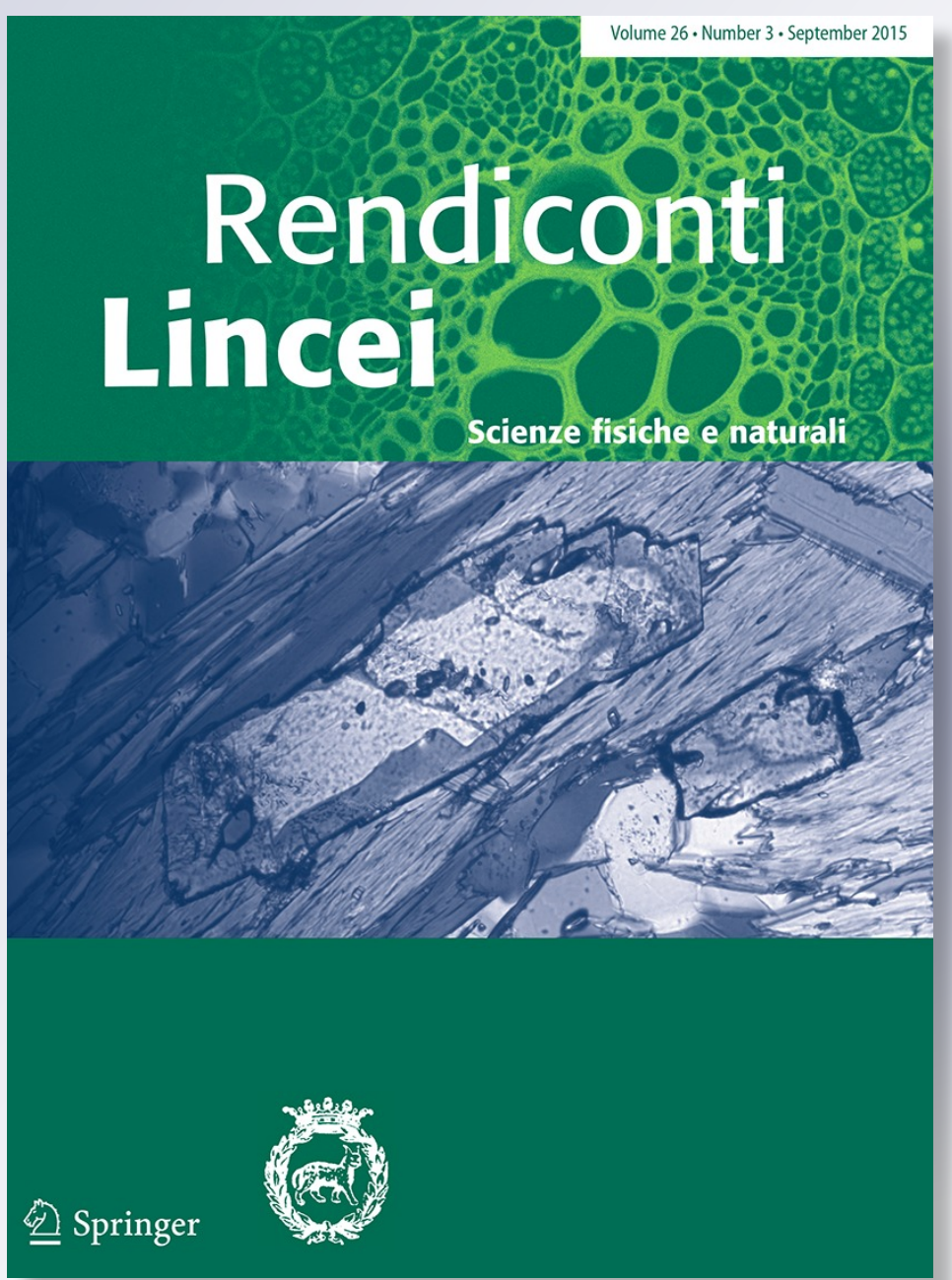

包 Springer 
Your article is protected by copyright and all rights are held exclusively by Accademia Nazionale dei Lincei. This e-offprint is for personal use only and shall not be selfarchived in electronic repositories. If you wish to self-archive your article, please use the accepted manuscript version for posting on your own website. You may further deposit the accepted manuscript version in any repository, provided it is only made publicly available 12 months after official publication or later and provided acknowledgement is given to the original source of publication and a link is inserted to the published article on Springer's website. The link must be accompanied by the following text: "The final publication is available at link.springer.com". 


\title{
A test on Ellenberg indicator values in the Mediterranean evergreen woods (Quercetea ilicis)
}

\author{
Corrado Marcenò $^{1,2} \cdot$ Riccardo Guarino ${ }^{3}$
}

Received: 6 March 2015/Accepted: 19 June 2015 / Published online: 7 July 2015

(C) Accademia Nazionale dei Lincei 2015

\begin{abstract}
The consistency and reliability of Ellenberg's indicator values (Eiv) as ecological descriptors of the Mediterranean evergreen vegetation ascribed to the phytosociological class Quercetea ilicis have been checked on a set of 859 phytosociological relevés $\times 699$ species. Diagnostic species were identified through a Twinspan analysis and their Eiv analyzed and related to the following independent variables: (1) annual mean temperatures, (2) annual rainfall. The results provided interesting insights to disentangle the current syntaxonomical framework at the alliance level demonstrating the usefulness of ecological indicator values to test the efficiency and predictivity of the phytosociological classification.
\end{abstract}

Keywords Quercetea ilicis · Ecological indicators · Maquis $\cdot$ Scrublands $\cdot$ Mediterranean $\cdot$ Sicily

\section{Introduction}

Ellenberg's indicator values (Eiv) have been described by the author himself as an empirical tool to express the ecological response of plants to the environment,

Riccardo Guarino

guarinotro@hotmail.com

1 Institute of Biosciences and BioResources (IBBR), CNR, Corso Calatafimi 414, 90129 Palermo, Italy

2 Department of Botany and Zoology, Masaryk University, Kotlarska, 2-61137, Brno, Czech Republic

3 Botanical Unit, Department of Biological, Chemical and Pharmaceutical Sciences and Technologies (STEBICEF), University of Palermo, Via Archirafi 38, 90123 Palermo, Italy recognizing the role of each species as a biological indicator (Ellenberg 1974; Ellenberg et al. 1992). Since their publication, Eiv have been applied, checked and validated in a large number of contributions dealing with the Central European flora and vegetation (see Diekmann 2003, for a review). From Central Europe, Eiv have been extended to Poland (Zarzycky 1984), Hungary (Borhidi 1995), Britain (Hill et al. 1999) and the Faroe Islands (Lawesson et al. 2003).

This enlargement was rather unproblematic owing to a large number of species in common and a comparable latitudinal range between these countries.

In recent years, the model was extended with some adjustments to the flora of the south-Aegean Region (Böhling et al. 2002) and that of Italy (Pignatti et al. 2005). The shared species in Ellenberg's original list (Ellenberg et al. 1992) and the two aforementioned floras are approx. $18 \%$ for the south-Aegean Region and $37 \%$ for Italy. In general, the edaphic values (Humidity: $F, \mathrm{pH}: R$, Nutrients: $N$, Salinity: $S$ ) of the species in common were left untouched, while those referring to climatic variables (Light: $L$, Temperature: $T$, Continentality: $C$ ) have been partially adjusted by the respective authors, based on the assumption that environmental conditions in the Mediterranean can be much different from those in Central Europe and the fact that it is highly unlikely that most species behave similarly in the two regions, at least in absolute terms.

The adjustments made in Böhling et al. were more extensive than in Pignatti et al.; however, it is important to consider that these last authors extended the $L$ and $T$ scales to 12 values (the original scale was 1-9) to account for higher radiation and temperatures occurring in the Mediterranean due to lower latitudes.

An important feature of Eiv is that they are related to the ecological optimum of a given species, which can vary 
from region to region (Gégout and Krizova 2003). Moreover, the two lists mentioned so far available for the Mediterranean region are based on expert knowledge alone and, as declared by the authors, both lists are amenable to further adjustments. Whereas the values and the use of mean values as surrogates for measured environmental factors are since long established as important tools in plant ecology in Central Europe, applications in the Mediterranean are scarce up to now. For this reason, their applicability in the Mediterranean region needs to be validated (Godefroid and Dana 2007), also because in such an heterogeneous patchwork of ecosystems there are many ways in which the conclusions drawn by the use of Eiv may be affected by their degree of accuracy and of suitability.

Most of the applications of Eiv in the Mediterranean region were aimed at "fingerprinting" the ecological context of plant communities described by floristic composition (Lucchese and Monterosso 1994; Pignatti 1998, 1999; Pignatti et al. 1996, 2001; Guarino and Bernardini 2002; Fanelli 2002; Bianco et al. 2003; Fanelli et al. 2006a b; Gristina and Marcenò 2008; Mossa et al. 2008; Brunialti et al. 2010); however, the correlation between mean values with related environmental variables has been checked only in very few contributions (Fanelli et al. 2006c; Testi et al. 2009, 2012, Sicuriello et al. 2014; Guarino et al. 2014) and for very limited vegetation units.

This study aims at testing the consistency of Eiv with broad scale climatic variables in some of the most representative Mediterranean vegetation types, i.e., the evergreen maquis and woodlands/forests ascribed to the phytosociological class Quercetea ilicis Br.-Bl. ex A. e O. Bolòs and Bolòs (1950). Although the class Quercetea ilicis is widely distributed all around the Mediterranean basin, it was decided to focus on a regional subset of data to avoid possible biases from biogeographic factors.

\section{Materials and methods}

\subsection{Study area}

Sicily represents an ideal study area for these purposes due to its central position in the Mediterranean basin and its relatively limited latitudinal and longitudinal range, along with a substantial amplitude of ecological gradients and a wide distribution of the Quercetea ilicis vegetation in its territory (Raimondo et al. 2013). The ecological plasticity of the Sicilian Quercetea ilicis stands is further demonstrated by its phytosociological diversity: according to the most recent vegetation survey (Brullo et al. 2008), this class is represented in Sicily by 47 phytosociological associations, distributed from the sea level up to $1600 \mathrm{~m}$ a.s.l., under different climatic and edaphic conditions (Bazan et al. 2015).

\subsection{Data sets}

A database of 1185 phytosociological relevés ascribed to the class Quercetea ilicis was compiled and stored in Turboveg (Hennekens and Schaminée 2001). The collected relevés included all the phytosociological literature available from Sicily to neighbouring islets (for a reference list, see Brullo et al. 2008), plus 39 unpublished relevés stored in the archives of Vegitaly (Landucci et al. 2012; Gigante et al. 2012). All data were sampled according to the phytosociological method of the ZürichMontpellier school (Braun-Blanquet 1964). The database included 742 species, whose taxonomic nomenclature was standardized following the checklist of the sicilian flora (Giardina et al. 2007).

It must be noted that 198 species of our data set were also included in Ellenberg's original list but only 12 of them were occurring in more than 24 relevés, i.e. more than $2 \%$ of our data set (see Table 1 for more details).

The relevés without explicit indication of their geographical coordinates were geo-referenced using the WebGIS of the IGM (Military Geographical Institute), which permits achieving a reasonably good approximation through comparison of aerial photographs with the highly detailed IGM data-base of Italian toponyms (Fig. 1).

Mean Ellenberg indicator values (mean Eiv) and climatic variables (Cvs) were assigned to each relevé. Eiv followed the list produced by Pignatti et al. (2005) for the Italian flora and its recent update (Guarino et al. 2012). The Cvs assigned to each relevé were annual mean temperature (Temp) and annual rainfall ( $P$ rec), obtained through the overlay of the distribution map of the phytosociological relevés to the Worldclim raster (Hijmans et al. 2005), by means of the ArcGis software (ESRI 2011). In order to achieve a reasonably good approximation of the Cvs, rasters of 30 arc-seconds were adopted, corresponding to a spatial resolution of $\sim 1 \mathrm{~km}$.

\subsection{Data resampling}

To avoid pseudoreplication, the initial data set was divided into 47 subsets, based on the phytosociological associations to which relevés were originally ascribed by their respective authors, and geographically resampled to delete part of the most similar relevés, sampled in the same locality. In this first resampling, max. 5 relevés were deleted in each subset. This new dataset was spread on a grid of 1.25 longitudinal by 0.75 latitudinal minutes (Knollová et al. 2005) and max. 5 relevés per cell have been selected by means of the Heterogeneity-Constrained Random (HCR) resampling algorithm (Lengyel et al. 2011) with BrayCrutis dissimilarity. The resampled data set consisted of 859 relevés by 699 species. 
Table 1 Synoptic table of the diagnostic species ( $\Phi$ coefficient $\geq 35$ ), constant species (relative frequency $\geq 25 \%$ ) and dominant species (cover value $\geq 25 \%$ in at least $6 \%$ of the relevés) in the processed relevés

\begin{tabular}{|c|c|c|c|}
\hline & Diagnostic species & Constant species & Dominant species \\
\hline $\begin{array}{c}\text { Cluster } \\
1(18)\end{array}$ & $\begin{array}{l}\text { Centaurea sphaerocephala 81.4, Cutandia } \\
\text { divaricata 52.3, Echinophora spinosa } 40.5 \text {, } \\
\text { Elytrigia juncea 46.8, Ephedra fragilis } \\
\text { 46.6, Eryngium maritimum } 40.5, \\
\text { Euphorbia terracina } 60.6, \text { Juniperus } \\
\text { oxycedrus s. macrocarpa } 78.7 \text {, Launea } \\
\text { fragilis } 74.2 \text {, Medicago marina } 40.5, \\
\text { Ononis hispanica s. ramosissima } 74.8, \\
\text { Pancratium maritimum } 70.3 \text {, Pseudorlaya } \\
\text { pumila } 46.8 \text {, Retama raetam s. gussonei } \\
\text { 43.9, Scolymus hispanicus } 37.8 \text {, Seseli } \\
\text { tortuosum v. maritimum } 70.3 \text {, Silene } \\
\text { nicaeensis } 46.8\end{array}$ & $\begin{array}{l}\text { Asparagus acutifolius 56, Asparagus } \\
\text { horridus 28, Daucus carota 28, Lycium } \\
\text { intricatum 28, Phillyrea latifolia 28, } \\
\text { Pistacia lentiscus 67, Prasium majus 56, } \\
\text { Rubia peregrina 50 }\end{array}$ & $\begin{array}{l}\text { Ephedra fragilis } 17 \text {, Juniperus oxycedrus s. } \\
\text { macrocarpa 56, Phillyrea latifolia } 11, \\
\text { Pistacia lentiscus } 28 \text {, Retama raetam s. } \\
\text { gussonei } 28\end{array}$ \\
\hline $\begin{array}{c}\text { Cluster } \\
2(31)\end{array}$ & $\begin{array}{l}\text { Anagallis arvensis } 35.3 \text {, Cistus } \\
\text { monspeliensis } 39.2 \text {, Coronilla scorpioides } \\
\text { 58.9, Fumana thymifolia } 43.1 \text {, Galium } \\
\text { murale } 40.2 \text {, Globularia alypum } 64.1, \\
\text { Hippocrepis biflora } 39.5 \text {, Ononis reclinata } \\
\text { 39.5, Ophrys sphecodes } 39.5 \text {, Pinus } \\
\text { halepensis } 78.9 \text {, Ranunculus macrophyllus } \\
\text { 35.3, Rosmarinus officinalis } 71.0 \text {, Serapia } \\
\text { vomeracea } 66.5 \text {, Sulla spinosissima } 49.8 \text {, } \\
\text { Valantia muralis } 43.6\end{array}$ & $\begin{array}{l}\text { Ampelodesmos mauritanicus 48, Arisarum } \\
\text { vulgare 29, Asparagus acutifolius } 71 \text {, } \\
\text { Asphodelus ramosus 35, Calicotome } \\
\text { infesta 42, Chamaerops humilis 39, Cistus } \\
\text { creticus s. eriocephalus 35, Cistus } \\
\text { salvifolius } 65 \text {, Coridothymus capitatus } 61 \text {, } \\
\text { Cytinus hypocistis 26, Erica multiflora 55, } \\
\text { Olea europaea v. sylvestris 39, Phagnalon } \\
\text { rupestre 32, Phillyrea latifolia 52, Pistacia } \\
\text { lentiscus 90, Prasium majus 42, Quercus } \\
\text { calliprinos 26, Rubia peregrina 29, } \\
\text { Teucrium fruticans } 71\end{array}$ & $\begin{array}{l}\text { Cistus monspeliensis 13, Pinus halepensis } \\
74 \text {, Pistacia lentiscus 13, Rosmarinus } \\
\text { officinalis } 45\end{array}$ \\
\hline $\begin{array}{c}\text { Cluster } \\
3(93)\end{array}$ & $\begin{array}{l}\text { Coronilla valentina } 38.8 \text {, Euphorbia } \\
\text { dendroides 51.3, Micromeria graeca s. } \\
\text { fruticulosa 43.7, Periploca laevigata s. } \\
\text { angustifolia } 75.0 \text {, Phagnalon saxatile v. } \\
\text { viride } 36.9 \text {, Senecio cineraria } 42.0\end{array}$ & $\begin{array}{l}\text { Arisarum vulgare } 35 \text {, Asparagus acutifolius } \\
66 \text {, Asphodelus ramosus } 46 \text {, Bituminaria } \\
\text { bituminosa } 32 \text {, Dactylis glomerata s. } \\
\text { hispanica } 40 \text {, Hyparrhenia hirta } 45 \text {, Olea } \\
\text { europaea v. sylvestris 57, Phagnalon } \\
\text { saxatile } 40 \text {, Pistacia lentiscus } 86 \text {, Prasium } \\
\text { majus } 74 \text {, Rhamnus lycioides s. oleoides } \\
\text { 26, Ruta chalepensis } 39 \text {, Teucrium } \\
\text { fruticans } 49\end{array}$ & $\begin{array}{l}\text { Euphorbia dendroides } 45 \text {, Periploca } \\
\text { laevigata s. angustifolia } 26 \text {, Pistacia } \\
\text { lentiscus } 14\end{array}$ \\
\hline $\begin{array}{l}\text { Cluster } \\
\quad 4 \\
(329)\end{array}$ & $\begin{array}{l}\text { Chamaerops humilis } 43.3 \text {, Olea europaea v. } \\
\text { sylvestris } 39.9 \text {, Pistacia lentiscus } 39.0 \text {, } \\
\text { Prasium majus } 42.0 \text {, Teucrium fruticans } \\
45.4\end{array}$ & $\begin{array}{l}\text { Ampelodesmos mauritanicus 46, Arisarum } \\
\text { vulgare 43, Asparagus acutifolius } 74, \\
\text { Asparagus albus } 28 \text {, Asphodelus ramosus } \\
\text { 31, Calicotome infesta 59, Ceratonia } \\
\text { siliqua 26, Charybdys pancration } 30, \\
\text { Dactylis glomerata s. hispanica 28, } \\
\text { Daphne gnidium 26, Euphorbia dendroides } \\
\text { 44, Lonicera implexa 28, Micromeria } \\
\text { graeca 30, Phillyrea latifolia 39, Rhamnus } \\
\text { alaternus 26, Rubia peregrina 55, Smilax } \\
\text { aspera 45, Teucrium flavum } 28\end{array}$ & $\begin{array}{l}\text { Calicotome infesta } 13 \text {, Chamaerops humilis } \\
\text { 6, Euphorbia dendroides } 18 \text {, Olea europaea } \\
\text { v. sylvestris } 6 \text {, Pistacia lentiscus } 26 \text {, } \\
\text { Quercus ilex } 10\end{array}$ \\
\hline $\begin{array}{l}\text { Cluster } \\
5 \\
(156)\end{array}$ & $\begin{array}{l}\text { Achillea ligustica 44.1, Anthoxanthum } \\
\text { odoratum 47.5, Asplenium onopteris 41.6, } \\
\text { Brachypodium sylvaticum 49.2, Carex } \\
\text { distachya 48.5, Clinopodium vulgare s. } \\
\text { orientale 58.5, Crepis leontodontoides } \\
\text { 50.2, Cytisus villosus 63.7, Drymochloa } \\
\text { drimeja 57.0, Erica arborea 61.6, Genista } \\
\text { monspessulana 39.1, Luzula forsteri } 65.2 \text {, } \\
\text { Oenanthe pimpinelloides 42.1, Pimpinella } \\
\text { anisoides 39.8, Poa sylvicola 42.6, } \\
\text { Pteridium aquilinum 63.8, Pulicaria odora } \\
\text { 51.2, Quercus congesta 57.6, Quercus } \\
\text { dalechampii 76.4, Quercus suber } 35.2, \\
\text { Rubus ulmifolius 35.7, Teucrium } \\
\text { chamaedrys } 35.4, \text { Teucrium scorodonia s. } \\
\text { crenatifolium 63.1, Viola alba s. } \\
\text { denhardthii } 44 .\end{array}$ & $\begin{array}{l}\text { Allium subhirsutum 36, Ampelodesmos } \\
\text { mauritanicus 26, Arisarum vulgare 28, } \\
\text { Asparagus acutifolius } 72 \text {, Calicotome } \\
\text { infesta } 65 \text {, Cistus salvifolius 27, Crataegus } \\
\text { monogyna 29, Cyclamen hederifolium 47, } \\
\text { Daphne gnidium } 30 \text {, Euphorbia characias } \\
\text { 33, Hedera helix 45, Lonicera etrusca } 29 \text {, } \\
\text { Melica minuta 29, Quercus ilex 56, Rosa } \\
\text { sempervirens 49, Rubia peregrina } 63 \text {, } \\
\text { Ruscus aculeatus 58, Smilax aspera } 31 \text {, } \\
\text { Tamus communis } 26\end{array}$ & $\begin{array}{l}\text { Arbutus unedo } 8 \text {, Calicotome infesta 9, } \\
\text { Cytisus villosus 19, Erica arborea 17, } \\
\text { Pteridium aquilinum 8, Quercus congesta } \\
\text { 13, Quercus dalechampii 10, Quercus ilex } \\
\text { 28, Quercus suber 24, Quercus virgiliana } \\
\text { 13 }\end{array}$ \\
\hline
\end{tabular}


Table 1 continued

\begin{tabular}{clll}
\hline & Diagnostic species & Constant species & Dominant species \\
\hline Cluster & Clematis vitalba 46.4, Dryopteris pallida & Acanthus mollis 34, Allium subhirsutum 45, & Bupleurum fruticosum 6, Hedera helix 6, \\
6 & 40.0, Fraxinus ornus 45.5, Hedera helix & Ampelodesmos mauritanicus 26, & Laurus nobilis 8, Ostrya carpinifolia 9, \\
$(232)$ & 56.9, Laurus nobilis 35.4, Quercus ilex & Asparagus acutifolius 72, Asplenium & Quercus amplifolia 7, Quercus ilex 48, \\
& 48.4, Quercus virgiliana 44.7, Ruscus & onopteris 36, Brachypodium sylvaticum & Quercus virgiliana 22, Ruscus aculeatus 6 \\
& aculeatus 49.7, Tamus communis 45.0 & 36, Carex distachya 33, Crataegus & \\
& & monogyna 35, Cyclamen hederifolium 37, & \\
& & Cyclamen repandum 34, Euphorbia & \\
& characias 36, Osyris alba 26, Rhamnus & \\
& & alaternus 41, Rosa sempervirens 47, Rubia & \\
& peregrina 79, Rubus ulmifolius 53, Smilax & \\
& aspera 48, Teucrium flavum 26 & \\
\hline
\end{tabular}

The number of relevés per cluster is reported inside brackets

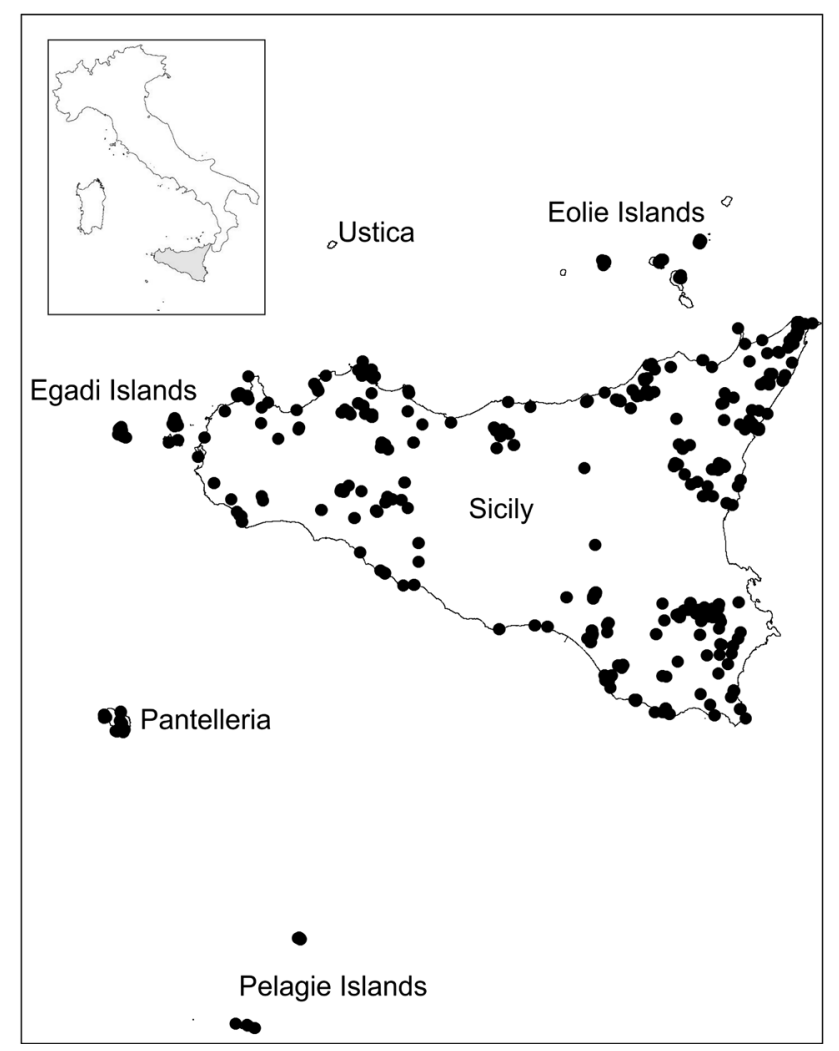

Fig. 1 Geographical distribution of the processed data

\subsection{Classification and ordination analysis}

A Twinspan analysis (Hill 1979), modified according to Roleček et al. (2009), was performed on the resampled dataset by means of the JUICE software (Tichý 2002). The analysis was based on the following settings: (i) max. number of clusters: 15 (arbitrary); (ii) min. group size for division: 5. With the aim to evaluate the compositional dissimilarity between the relevés, the average Sørensen dissimilarity index was adopted for clustering. The optimal number of clusters was then assessed by means of a crispness analysis (Botta-Dukát et al. 2005). The calculation of crispness was based on 10 species randomly selected among those having more than 50 occurrences in the resampled data set.

In order to analyse the variation in species composition, a DCA was performed on square root transformation of data + downweighting of rare species on the whole set of relevés, by means of the $\mathrm{R}$ software VEGAN package (Oksanen et al. 2009).

The correlation between the considered Cvs (Temp, $P$ rec) and the mean $\operatorname{Eiv}(L, T, F, N, R)$, as well as their correlation with the first axis of the DCA, were calculated through the Kendall correlation coefficient (Bolboacă and Jäntschi 2006).

Diagnostic species of each group were determined using the $\varphi$ coefficient, which indicates the fidelity of a given taxon to a particular group (Sokal and Rohlf 1995; Chytrý et al. 2002). Only taxa with a $\varphi$ coefficient higher than 0.35 and a probability of occurrence under random expectation lower than 0.01 (Fisher's exact test) were considered to be diagnostic for each group. Constant species were defined as those with a frequency $>35 \%$ within each group. Dominant species were defined as those occurring in at least $6 \%$ of the relevés of a given group with a cover value $>25 \%$.

\subsection{Eiv assessment}

Even if Eiv consist of ordinal adimensional scales, in large data sets they can be processed with parametric tests, because their distribution fits the normal curve (ter Braak and Barendregt 1986; Pignatti et al. 2001).On the other hand, even if the Cvs obtained from Worldclim raster are independent from Eiv, any kind of environmental variable influencing the species composition in the vegetation plots could be indirectly correlated with Eiv (Zelený and Schaffers 2012), that is, the significance tests between ordination outputs and Eiv were further checked through a modified permutation test (MoPeT, 499 permutations), 
which calculates the correct significance values for regression or correlation between mean Eiv and other environmental variables (Zelený 2014).

In particular, the modified randomization test was performed to check (i) the significance of the differences among the Eiv in the Twinspan groups revealed by a oneway ANOVA and (ii) the significance of the observed linear regressions between the Ellenberg's mean $T, F$ and the mean temperature ( $T$ mean) and annual rainfall $(P$ rec $)$, respectively.

\section{Results}

\subsection{Classification and ordination analysis}

The Twinspan analysis combined to the crispness evaluation suggested to split the processed data set into 6 clusters, for which the max. dissimilarity score evaluated by the Sørensen index was 0.75 and the min. 0.73.

The analysis of diagnostic species (Table 1) revealed that the clusters $1-4$ are characterized by a set of thermoheliophilous species, partially coherent with those used in phytosociological literature to characterize the order Pistacio lentisci-Rhamnetalia alaterni Rivas-Martínez 1975. The diagnostic species of clusters 4-5 were relatively more mesophilous and coherent with the chief species of the order Quercetalia ilicis Br.-B1. ex Molinier (1934) (Brullo et al. 2008).

In particular, cluster 1 groups the relevés ascribed to Juniperion turbinatae Rivas-Martínez 1975, cluster 2 groups the relevés of Pistacio lentisci-Pinetum halepensis De Marco and Caneva (1985), cluster 3 groups the relevés ascribed to Periplocion angustifoliae Rivas-Martínez 1975, cluster 4 groups the relevés ascribed to Oleo sylvestrisCeratonion siliquae Br.-Bl. ex Guinochet and Drouineau (1944), cluster 5 groups the relevés ascribed to EricoQuercion ilicis Brullo, Di Martino \& Marcenò 1977 (Group_5) and cluster 6 groups the relevés ascribed to Quercion ilicis Br.-Bl. ex Molinier (1934).

The DCA (Fig. 2) highlighted two opposite climatic gradients, oriented along the first axis: the light $(L)$ and temperature $(T)$ resulted correlated with $T$ mean, whereas moisture $(F)$ and nutrients $(N)$ resulted correlated with $P$ rec. The Kendall correlation $(K)$ values of Eiv and Cvs with the firs axis of DCA were the following: Light (L) $K=0.65, p<0.001$; Temperature (T) $K=0.70$, $p<0.001$; mean temperature ( $T$ mean) $K=0.52$, $p<0.001$; Continentality (C) $K=-0.09, p<0.001$; Moisture $(F) \quad K=-0.64, \quad p<0.001$; Nutrients (N) $K=-0.63, p<0.001$; Soil Reaction $(R) K=-0.10$, $p<0.001$; annual rainfall $(P$ rec) $K=-0.4, p<0.001$. The positive correlations resulted to be oriented towards the clusters 1-4 and the negative correlations towards clusters 5-6.

\subsection{Eiv assessment}

The randomized test of the one-way ANOVA performed on the Eiv provided significant results in four cases (Fig. 3); continentality $(C)$ and soil reaction $(R)$ did not provide significant results. The $95 \% \mathrm{CI}$ of the Eiv resulted to be relatively narrow in each cluster. The ecological differences between the associations ascribed to the clusters 1-4 and 5-6 are reflected by the variation of the mean Eiv $L, T$, $N, F$; in particular, clusters 1-4 were characterized by higher $L$ and $T$ values and by lower $F$ and $N$ values in comparison to clusters 5-6. The distribution of the
Fig. 2 DCA 3D of the considered Cvs (Temp average temperature; $P$ rec average precipitation) and Eiv ( $L$ light; $T$ temperature; $F$ moisture; $R$ soil reaction; $N$ nutrients; $C$ continentality) across data sets. In the diagram, Cvs and Eiv that showed a significant goodness of fit based on post hoc correlations are represented as vectors. The main floristic descriptors of the spiderplots identifying the 6 groups are reported in Table 1. Kendall's correlation between DCA axes 1 and environmental variables is reported in result's paragraph

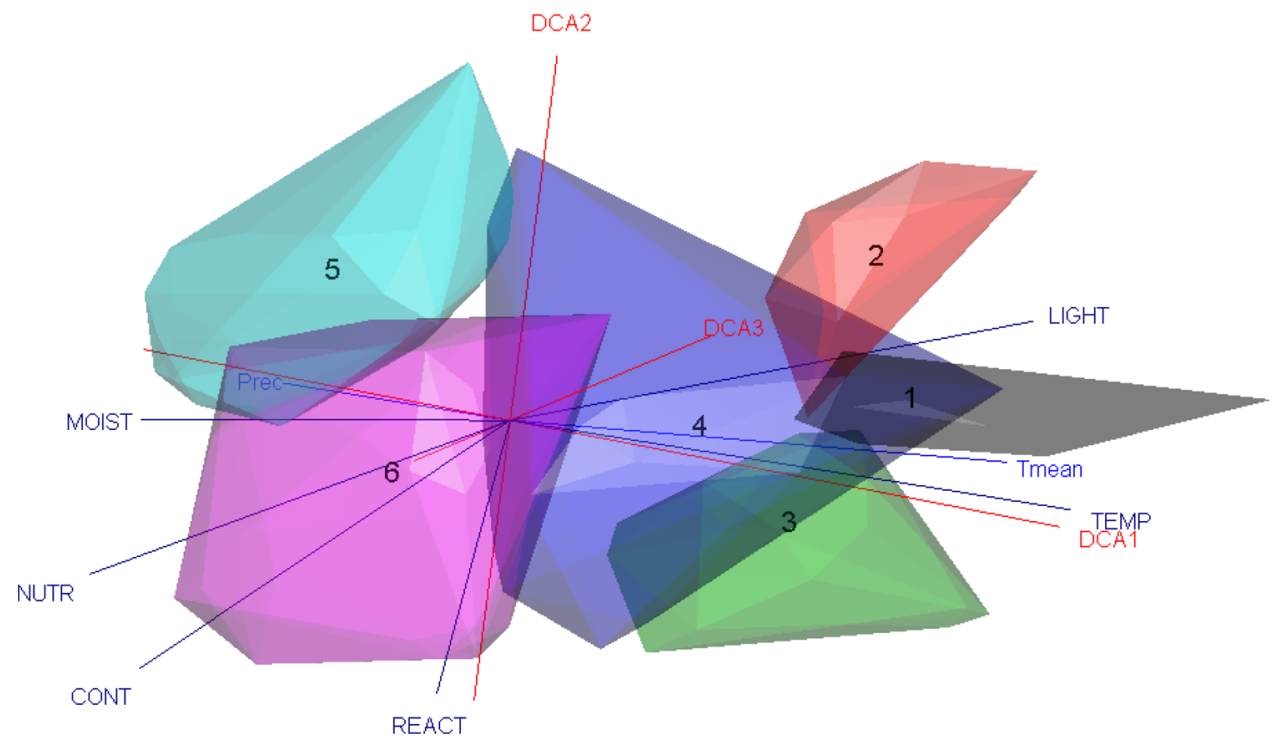


$F=617.821$, P. modif $<0.01$

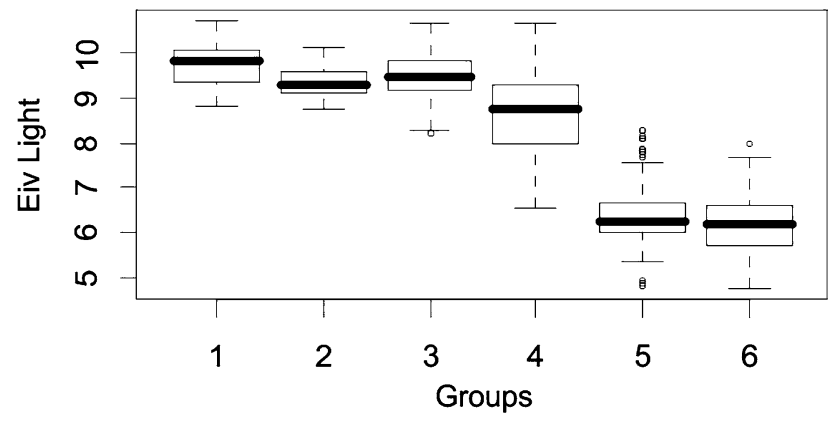

$F=88.010$, P.modif $=0.257$

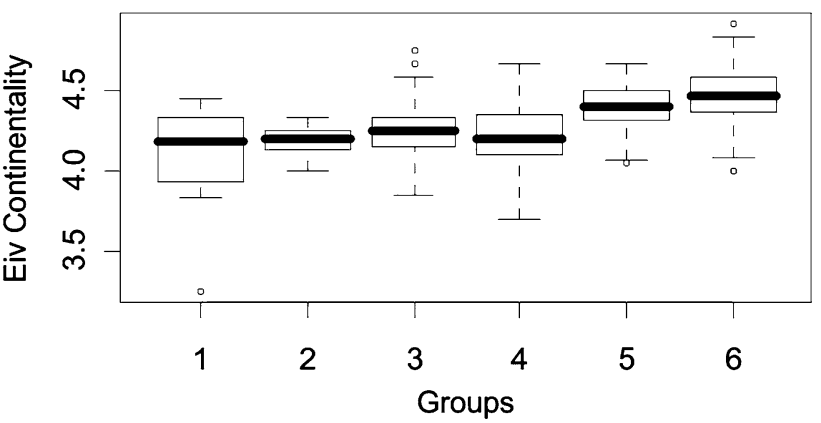

$F=36.006$, P.modif $=0.446$

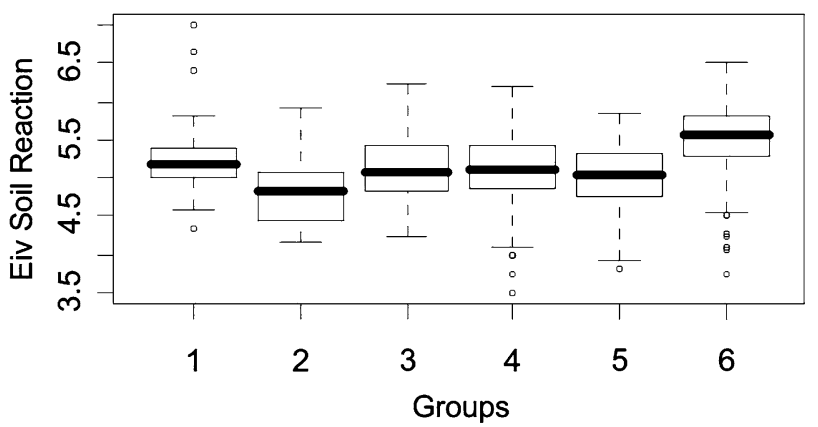

$F=469.158$, P.modif $<0.05$
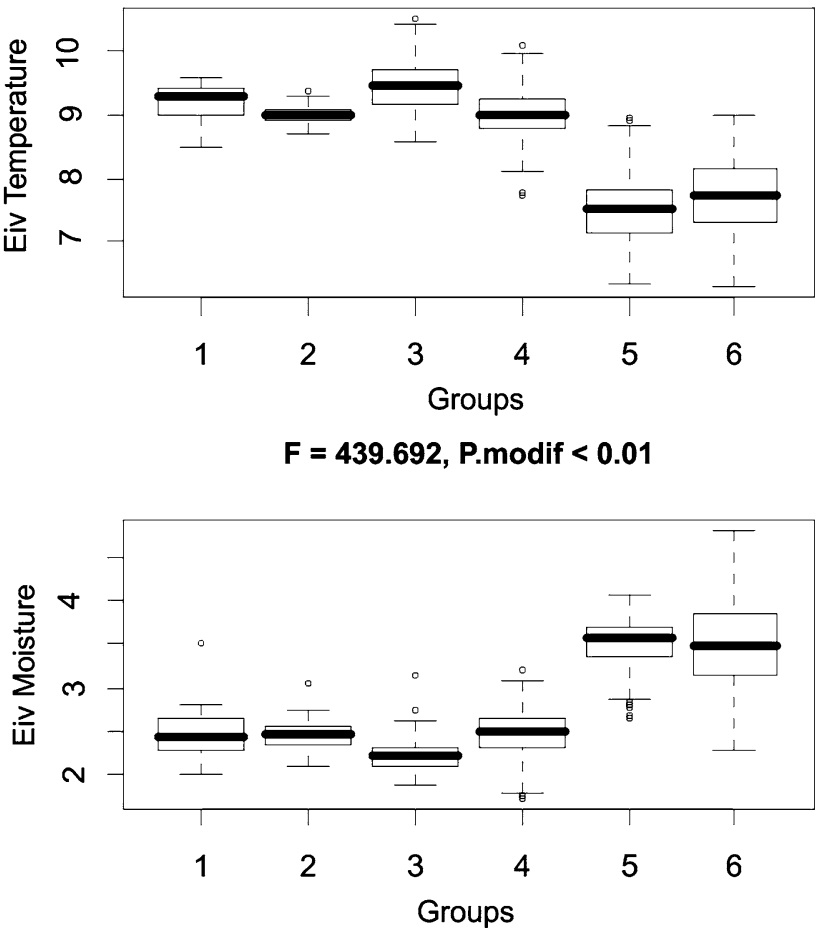

$F=340.733$, P.modif $<0.01$

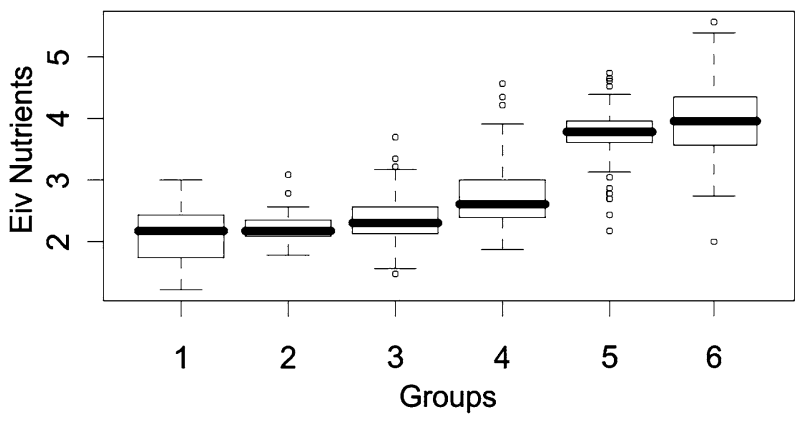

Fig. 3 One-way anova of the Eiv among the considered groups (boxes outline the $95 \% \mathrm{CI}$ ). $F$ ratio of the variability between groups compared to the variability within the groups; Significance $(P)$ modified according to Zelený (2014)

significant Eiv between clusters 1-4 vs. 5-6 do not overlap in all cases. Some differences have been revealed also across single clusters, see, for instance, the lower moisture (F) of the vegetation of Periplocion angustifoliae (cluster 3 ) in comparison with the other clusters ascribed to Pistacio lentisci-Rhamnetalia alaterni.

The regression analysis of the significant Eiv vs. the considered Cvs (Figs. 4, 5) showed significant results in all cases; in particular Temperature $(T)$ and annual mean temperature ( $T$ mean) are most related and, in general, the quadratic correlation coefficients $\left(R^{2}\right)$ of the annual rainfall $(P$ rec) resulted lower than those of $T$ mean.

\section{Discussion}

\subsection{Syntaxonomical remarks}

The clusters revealed by the Twinspan analysis resulted quite coherent with the phytosociological classification of the class Quercetea ilicis in Sicily. However, some discrepancies with the most recent vegetation survey (Brullo et al. 2008) have been highlighted too. In particular, it was impossible to detect any cluster that could be related to the alliances Ericion arboreae Rivas-Martínez (1975) 1987 and Arbuto unedonis-Laurion nobilis Rivas-Martínez 
R2 $=0.411$, P. modif $<0.01$

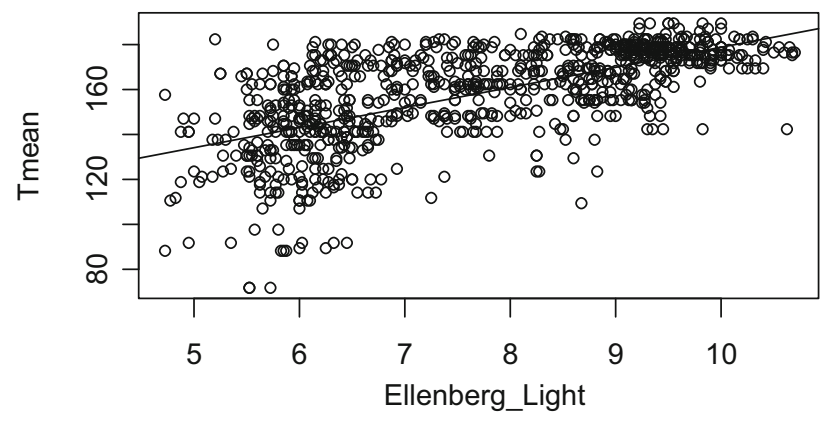

R2 $=0.203$, P. modif $<0.05$

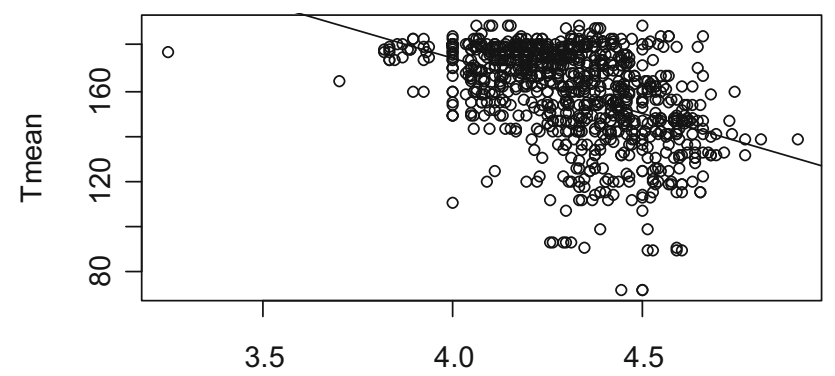

Ellenberg_Continentality

$\mathrm{R} 2=0.076$, P. modif $=0.198$

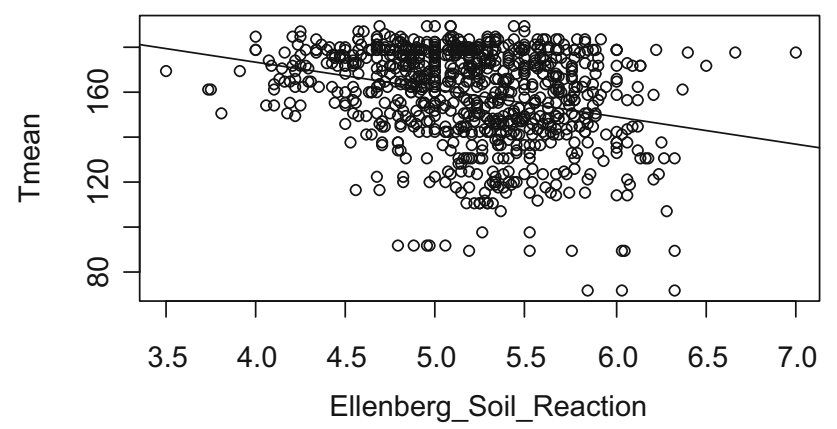

$\mathrm{R} 2=0.512$, P. modif $<0.01$

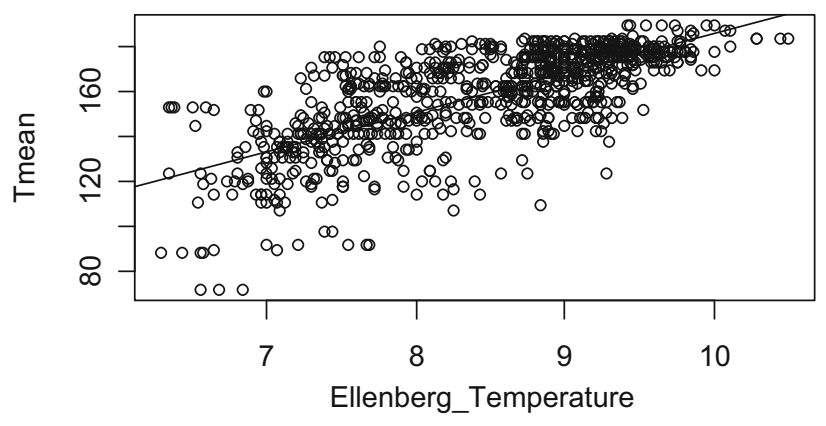

$R 2=0.437$, P. modif $<0.01$

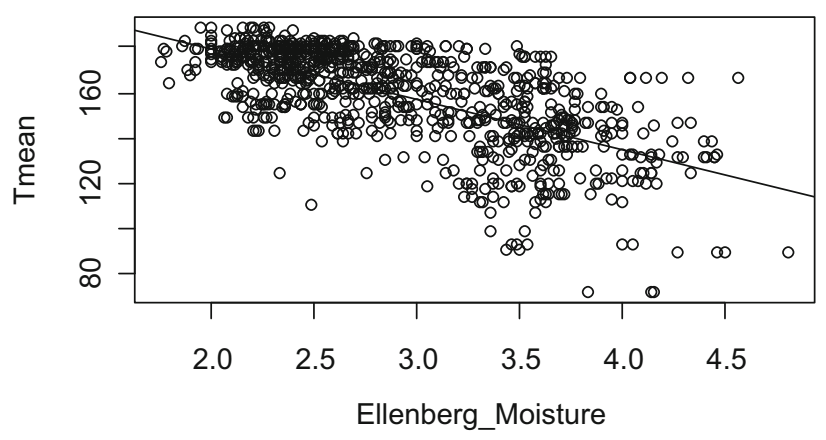

R2 $=0.397$, P. modif $<0.01$

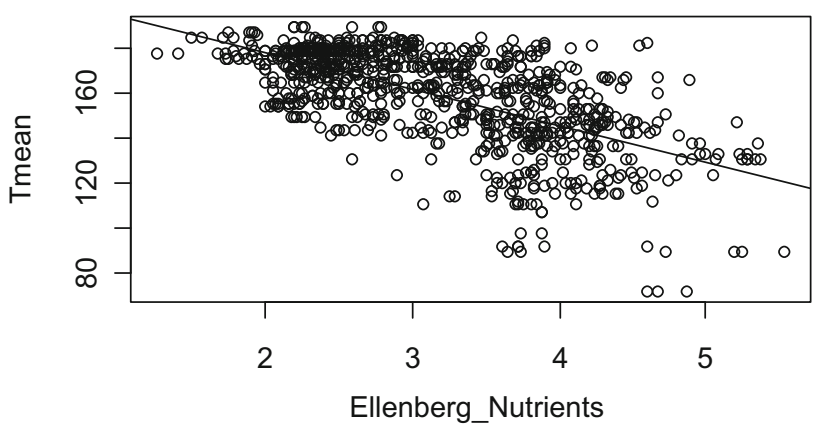

Fig. 4 Regression analysis between annual mean temperature ( $T$ mean) and Eiv. R2 R-squared; Significance $(P)$ modified according to Zelený (2014)

et al. (1999). These two alliances have been framed into the order Pistacio lentisci-Rhamnetalia alaterni, mostly because of the vegetation structure and syndynamic role (Rivas-Martínez et al. 2001; Bardat et al. 2004; Biondi et al. 2004b). Instead, in our numerical analysis, all the relevés originally attributed to the two alliances at issue were found to be merged into the cluster 5 , i.e. the one grouping the "moistest" and "coldest" stands of the vegetation processed in the present study. This is quite a reasonable evidence, if we consider that the two alliances at issue were originally described for the evergreen shrub communities of the Atlantic and submediterranean territories of Spain, rich in lauroid species, linked to hyperoceanic to thermo- mesotemperate bioclimates ( $\mathrm{Ri}$ vas-Martínez et al. 2001). Therefore, the recognition of these two alliances for the Tyrrhenian coasts of the Italian Peninsula and Sicily (Brullo et al. 2008; Biondi et al. 2014b) should be carefully considered, as well as their attribution to the order Pistacio lentisci-Rhamnetalia alaterni.

On the other hand, our analyses revealed quite clearly the occurrence of two clusters in the Quercetalia ilicis vegetation. This is in agreement with the classification proposed by Brullo et al. (2008), who split the order into Quercion ilicis and Erico-Quercion ilicis, and in contrast with the view of Biondi et al. (2014b) that recognizes 
R2 $=0.235$, P. modif $<0.01$

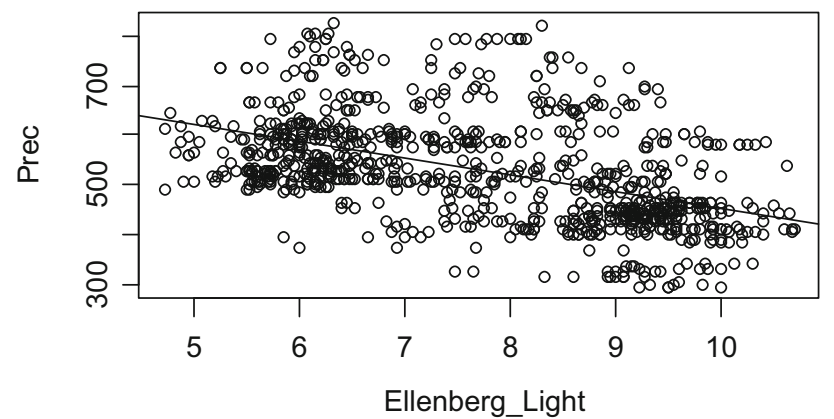

R2 $=0.135$, P. modif $<0.05$

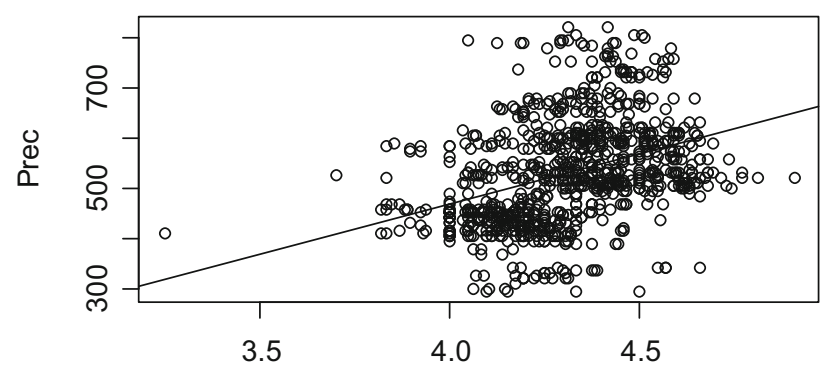

Ellenberg_Continentality

$\mathrm{R} 2=0.014$, P. modif $=0.505$

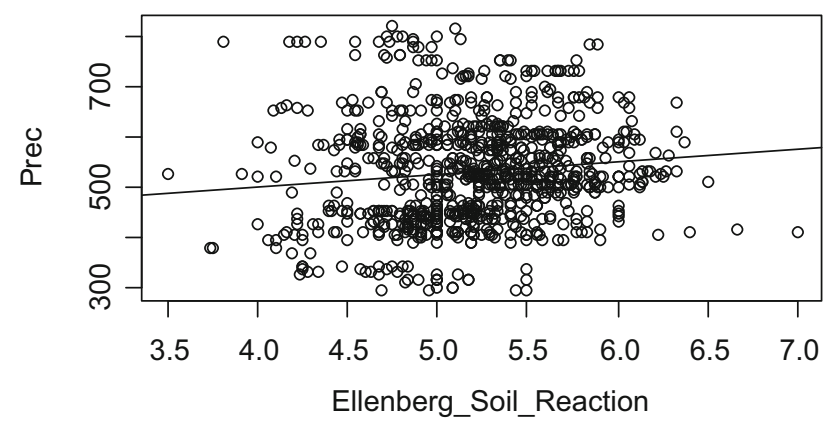

$\mathrm{R} 2=0.266$, P. modif $<0.01$

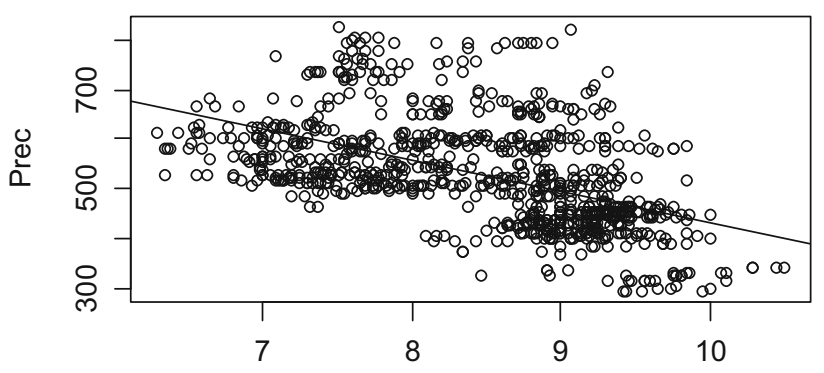

Ellenberg_Temperature

R2 $=0.233$, P.modif $<0.01$

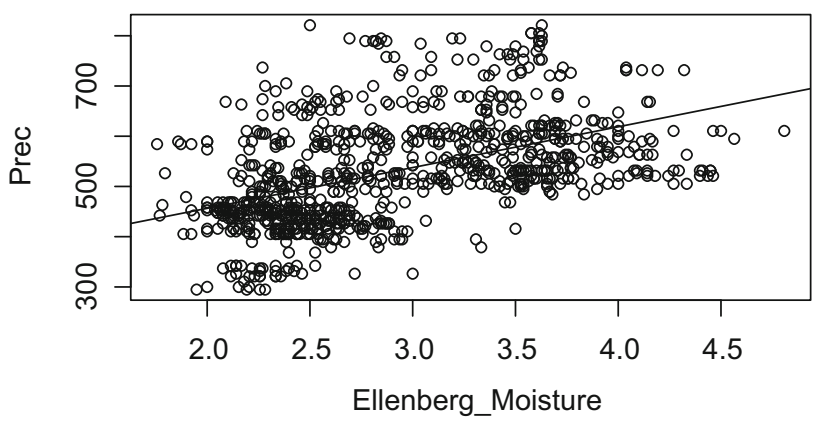

$\mathrm{R} 2=0.255$, P. modif $<0.05$

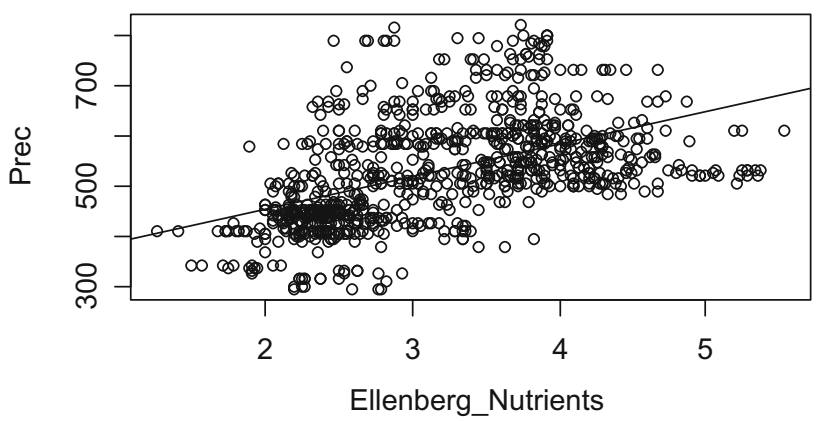

Fig. 5 Regression analysis between annual mean rainfall ( $P$ rec) and Eiv. $R 2$ R-squared; Significance $(P)$ modified according to Zelený (2014)

within the order only one alliance from the Italian territory: Fraxino orni-Quercion ilicis Biondi et al. (2013). Further and broader investigations would be desirable to disentangle this syntaxonomical issue.

Another result worth of discussion is related to the cluster 2, which groups the relevés of Pistacio lentisciPinetum halepensis: until recent times, this association was framed into the alliance Oleo sylvestris-Ceratonion siliquae; according to our results, its floristic settlement differs enough to propose its inclusion into the alliance Pistacio lentisci-Pinion halepensis Biondi, Blasi, Galdenzi, Pesaresi \& Vagge 2014. This last alliance has been recently described to group the vegetation dominated by Pinus halepensis, found on steep coastal slopes throughout the Mediterranean region (Biondi et al. 2014a). Further and broader investigations would be desirable to evaluate whether this recently described alliance deserves the recognition of an autonomous order, described as Pinetalia halepensis Biondi, Blasi, Galdenzi, Pesaresi \& Vagge 2014, which seems inconsistent with our results.

\subsection{Eiv assessment}

Up to now, the attention of scientists has mainly been focused on testing the consistency of Eiv by checking the correlation of their topographic variation with that of 
instrumental measurements (Degorski 1982; Seidling and Rohner 1993; Diekmann 1995; Petersen 2000; Wamelink et al. 2000, 2002, 2005). In the present study, the consistency of Eiv was tested in a representative area in the Central Mediterranean region and results are comparable, in terms of range and distribution of variance, to previous studies carried out in the Central European and Alpine regions (Möller 1997; Schaffers and Sýkora 2000; Pignatti et al. 2001). Moreover, basing on our results, the Eiv assigned to the diagnostic species proved to be relatively well linked to syntaxonomical units and their statistical distribution, evaluated by means of the ANOVA, can be considered sufficiently coherent and reliable to recommend their use in the ecological characterization of syntaxa, at least up to the alliance level.

The positive correlation of the $T, L$ indicator values with the mean annual temperature (Temp) can be explained by the life adaptations of the species characterizing clusters 1-4: all of them are adapted to live in habitats where high temperatures are always associated with intense solar radiation, determining a series of specific morphological and physiological traits commonly found in the plants forming the Mediterranean "maquis" (Guarino et al. 2006). This is the case for all diagnostic species of clusters 1-4 revealed by the Twinspan analysis on our data set. The correlation between $L$ and $T$ would not have been the same if, for instance, the Mediterranean oro-echinophytic vegetation had been considered in our analysis: in accordance with Wamelink et al. (2002), any observed significant correlation between different Eiv is largely dependent on the vegetation types analysed.

On the other hand, the positive correlation of $F$, $N$ indicator values with the mean annual rainfall $(P$ rec $)$ is in accordance with the results of previous studies on central-European wooden vegetation, in which these Eiv were related not only with the amount of precipitation, but also with the phreatic level, the water holding capacity and capillarity of the soil (Ellenberg et al. 1992, Ertsen et al. 1998, Schaffers and Sýkora 2000). In our case, the diagnostic species of clusters 5-6 include many sciaphilous herbaceous species, the occurrence of which is determined by the dense canopy of evergreen and semi-deciduous oaks, also included in the list of diagnostic species. For this reason, $F, N$ and $P$ rec were negatively correlated with $L$, $T$ and $T$ mean. A fairly good edaphic humidity, together with the lack of direct solar radiation, favours the humus formation process, providing a substantial improvement of the nutrient availability in the soil (Coûteaux et al. 1995; Zanella et al. 2011). Indeed, the nutrient availability in the vegetation of Pistacio lentisci-Rhamnetalia alaterni (clusters 1-4) tends to be lower because high temperatures, drought and solar radiation cause a quick oxidation of the organic matter and its periodical volatilization due to wildfires (González-Pérez et al. 2004), whereas the vegetation of Quercetalia ilicis (clusters 5-6) is less frequently burnt and produces more and better humus (Fioretto et al. 2007).

In our study, $R$ and $C$ did not show any significant variation. In the case of $R$ a possible reason could be that in the plant colonization of sites with seasonal water deficit, the ecological specialization to different edaphic conditions is less selective than the adaptation to a strong seasonal drought stress (Larcher 2001); therefore, it is difficult to detect purely acidophilous or basiphilous plant communities. In the case of $C$, the geographical gradient was too short to expect significant variations in the continentality of the vegetation analysed, because such Eiv can provide significant insights only along gradients encompassing two or more biogeographical regions and its applicability in the Mediterranean region remains questionable (Jelaska et al. 2014; Pignatti et al. 2005).

\section{Conclusions}

Wordclim climatic variables have never been used in combination with Eiv, with the exception of two studies referring to alpine or north-European ecosystems (Reger et al. 2011; Lenoir et al. 2013). In this study, such combination is proven to be a useful and consistent tool for the ecological characterization of the vegetation ascribed to the class Quercetea ilicis and provided interesting insights to disentangle the current syntaxonomical framework at the alliance level. The method followed here can be considered a modern take of the approach applied by Feoli and Lagonegro (1982) on the beechwoods of the Apennines. The use of Eiv can be applied to test the efficiency and predictivity of the phytosociological classification, strengthening the descriptive value of the phytosociological approach.

The reliability of the Eiv in the Mediterranean region has been criticized by Godefroid and Dana (2007), due to some discrepancies observed in the application of Eiv proposed for the south-Aegean Region (Böhling et al. 2002) and for Italy (Pignatti et al. 2005). Even if a recalibration of Eiv at a regional scale would be desirable to better reflect the local ecological behaviour of broadranging species, what should be remembered is that the utility of Eiv in environmental analyses derives from the simplicity of the model to carry out synthetic-comparative studies on relatively broad temporal and/or spatial scales. Any calibration or adjustment will unavoidably limit the general applicability of the model (Ter Braak and Gremmen 1987), even if it is likely that in the Mediterranean region the resolution power of Eiv is probably doomed to be lower than in Central Europe, due to the many factors (reviewed by Godefroid and Dana 2007) that make difficult 
"averaging" the ecological behaviour of broad-ranging species. However, it should be recognized that the Mediterranean region hosts many more narrow-ranging species than Central Europe, which in fact, could partially compensate the "blurred" Eiv of broad-ranging species. If the study of Godefroid and Dana (2007) had not been largely based on ruderal species, their conclusions would probably have been less pessimistic. The approach followed here, focusing on a single phytosociological class, is in our opinion a good way to proceed and we hope that this first contribution will be followed by similar ones, before deciding whether the development and subsequent application of Eiv in the Mediterranean Region is viable only on a local scale or not.

In agreement with Thompson et al. (1993), "generalisations about vegetation are urgently required to solve pressing problems created by modern land use, climate change and pollution. If one approaches vegetation with the tools of the watchmaker, there is no limit to the dissection which can be achieved. But if, like Heinz Ellenberg, one raises one's eyes to the broader canvas, the generalisations are there to be discovered".

Acknowledgments Forum Plinianum is gratefully acknowledged for the financial and scientific support; Ida Lindholm for linguistic revision. Thanks are due, as well, to the anonymous referees for their valuable observations and constructive criticism.

\section{References}

Bardat J, Bioret F, Botineau M, Boullet V, Delpech R, Géhu JM, Haury J, Lacoste A, Rameau JC, Royer JM, Roux G, Touffet J (2004) Prodrome des végétations de France. Muséum National d'Histoire Naturelle, Paris

Bazan G, Marino P, Guarino R, Domina G, Schicchi R (2015) Bioclimatology and vegetation series in Sicily: a geostatistical approach. Acta Bot Fenn 52:1-18

Bianco PM, Testi A, Belisario F, Guidotti S (2003) Vegetation patterns in the succession from wood fringes towards woodlands. Rend Fis Acc Lincei 9:135-160

Biondi E, Allegrezza M, Casavecchia S, Galdenzi D, Gigante D, Pesaresi S (2013) Validation of some syntaxa of Italian vegetation. Plant Biosyst 147:186-207

Biondi E, Allegrezza M, Casavecchia S, Galdenzi D, Gasparri R et al (2014a) New and validated syntaxa for the checklist of Italian vegetation. Plant Biosyst 148(1):318-332

Biondi E, Blasi C, Allegrezza M, Anzellotti I, Azzella MM et al (2014b) Plant communities of Italy: the vegetation prodrome. Plant Biosyst 148(4):728-814

Böhling N, Greuter W, Raus T (2002) Indicator values for vascular plants in the Southern Aegean (Greece). Braun-Blanquetia 32:1-109

Bolboacă SD, Jäntschi L (2006) Pearson versus spearman, Kendall's tau correlation analysis on structure-activity relationships of biologic active compounds. Leonardo J Sci 5:179-200

Bolòs A, Bolòs O (1950) Vegetación de las comarcas barcelonesas. Inst Esp Est Medit, Barcelona
Borhidi A (1995) Social behaviour types, the naturalness and relative ecological indicator values of the higher plants in the hungarian flora. Acta Bot Hungar 39:97-181

Botta-Dukát Z, Chytrý M, Hajkova P, Havlova M (2005) Vegetation of lowland wet meadows along a climatic continentality gradient in Central Europe. Preslia 77:89-111

Braun-Blanquet J (1964) Pflanzensoziologie Grundzüge der Vegetationskunde. Springer, Wien

Brullo S, Gianguzzi L, La Mantia A, Siracusa G (2008) La classe Quercetea ilicis in Sicilia. Boll Acc Gioenia Sci Nat Catania 41:1-124

Brunialti G, Frati L, Aleffi M, Marignani M, Rosati L, Burrascano S, Ravera S (2010) Lichens and bryophytes as indicators of oldgrowth features in Mediterranean forests. Pl Biosyst 144:221-233

Chytrý M, Tichý L, Holt J, Botta-Dukát Z (2002) Determination of diagnostic species with statistical fidelity measures. J Veg Sci 13:79-90

Coûteaux MM, Bottner P, Berg B (1995) Litter decomposition, climate and litter quality. Trends Ecol Evol 10(2):63-66

Degorski M (1982) Usefullness if Ellenberg bioindicators in characteristic plan communities and forest habitats on the basis of data from the range Grabowy in Kampinos Forest. Ekol Pol (Warsaw) 30:453-477

De Marco G, Caneva G (1985) Analisi sintassonomica e fitogeografica comparata di alcune significative cenosi a Pinus halepensis Mill. in Italia. Not Fitosoc 19:155-176

Diekmann M (1995) Use and improvement of Ellenberg's indicator values in deciduous forests of the boreo-nemoral zone in Sweden. Ecography 18:178-189

Diekmann M (2003) Species indicator values as an important tool in applied ecology-a review. Basic Appl Ecol 4:493-506

Ellenberg H (1974) Zeigerwerte der Gefässpflanzen Mitteleuropas. Scripta Geobot Göttingen 9

Ellenberg H, Weber HE, Düll R, Wirth V, Werner W, Paulissen D (1992) Zeigerwerte von Pflanzen in Mitteleuropa. Verlag Erich Goltze, Göttingen

Ertsen ACD, Alkemade JRM, Wassen MJ (1998) Calibrating Ellenberg indicator values for moisture, acidity, nutrient availability and salinity in The Netherlands. Plant Ecol 135:113-124

ESRI (2011) ArcGIS Desktop: release 10. Environmental Systems Research Institute, Redlands

Fanelli G (2002) Analisi fitosociologica dell'area metropolitana di Roma. Braun-Blanquetia 27:1-269

Fanelli G, Testi A, Pignatti S (2006a) Ecological indicator values for species in Central and Southern Italy flora. Accademia delle Scienze, Scritti e Documenti 37:505-564

Fanelli G, Pignatti S, Testi A (2006b) An application case of ecological indicator values (Zeigerwerte) calculated with a simple algorithmic approach. Plant Biosyst 141:15-21

Fanelli G, Tescarollo P, Testi A (2006c) Ecological indicators applied to urban and suburban floras. Ecol Indic 6:444-457

Feoli E, Lagonegro M (1982) Syntaxonomical analysis of beech woods in the Apennines (Italy) using the program package IAHOPA. Vegetatio 50:129-173

Fioretto A, Papa S, Pellegrino A, Fuggi A (2007) Decomposition dynamics of Myrtus communis and Quercus ilex leaf litter: mass loss, microbial activity and quality change. Appl Soil Ecol 36:32-40

Gégout JC, Krizova E (2003) Comparison of indicator values of forest understory plant species in Western Carpathians (Slovakia) and Vosges Mountains (France). Forest Ecol Manag 182:1-11

Giardina G, Raimondo FM, Spadaro V (2007) A catalogue of plants growing in Sicily. Bocconea 20:5-582 
Gigante D, Acosta ATR, Agrillo E, Attorre F, Cambria VE et al (2012) VegItaly: technical features, crucial issues and some solutions. Plant Sociol 49:69-80

Godefroid S, Dana ED (2007) Can Ellenberg's indicator values for Mediterranean plants be used outside their region of definition? J Biogeogr 34:62-68

González-Pérez JA, González-Vila FJ, Almendros G, Knicker H (2004) The effect of fire on soil organic matter-a review. Environ Internat 30:855-870

Gristina AS, Marcenò C (2008) Gli indici di bioindicazione di Pignatti-Ellenberg nello studio floristico-vegetazionale del promontorio di Capo Zafferano (Sicilia nord-occidentale). Naturalista Sicil 32:61-96

Guarino R, Bernardini A (2002) Indagine sulla diversità florovegetazionale del comprensorio del cuoio (Toscana centrosettentrionale). Tip Bongi, San Miniato (PI)

Guarino R, Domina G, Pignatti S (2012) Ellenberg's Indicator values for the Flora of Italy-first update: pteridophyta, Gymnospermae and Monocotyledoneae. Fl Medit 22:197-209

Guarino R, Bazan G, Paura B (2014) Downy-oak woods of Italy: phytogeographical remarks on a controversial taxonomic and ecologic issue. In: Box E, Fujiwara K (eds) Warm-temperate Deciduous Forests around the Northern Hemisphere. Geobotany Studies 8:139-152. doi:10.1007/978-3-319-01261-2_7

Guinochet M, Drouineau G (1944) Notes sur la vegetation et les sols aux environs d'Antibes (Alpes maritimes). Rec Trav Ist Bot Montpellier 1:22-40

Hennekens SM, Schaminée JHJ (2001) TURBOVEG, a comprehensive data base management system for vegetation data. J Veg Sci 12:589-591

Hijmans RJ, Cameron SE, Parra JL, Jones PG, Jarvis A (2005) Very high resolution interpolated climate surfaces for global land areas. Int J Climatol 25:1965-1978. http://www.worldclim.org/. Accessed 06 Dec 2014

Hill MO (1979) TWINSPAN A Fortran program for arranging multivariate data in an ordered two-way table by classification of the individuals and attributes. Cornell University, Ithaca, NY

Hill MO, Mountford JO, Roy DB, Bunce RGH (1999) Ellenberg's indicator values for British plants. Institute of Terrestrial Ecology, Huntingdon

Jelaska SD, Babic L, Skvirk Z, Nikolic T (2014) 40 years of Ellenberg's indicator values-do we need another 40 to complete values for Croatian flora? In: Carni A, Juvan N, Ribeiro D, (eds) 23rd International Workshop of the European Vegetation Survey-Book of Abstracts: 45-46

Knollová I, Chytrý M, Tichý L, Hájek O (2005) Stratified resampling of phytosociological databases: some strategies for obtaining more representative data sets for classification studies. J Veg Sci 16:479-486

Landucci F, Acosta ATR, Agrillo E, Attorre F, Biondi E et al (2012) VegItaly: the Italian collaborative project for a national vegetation database. Pl Biosyst 146:756-763

Larcher W (2001) Ökophysiologie der Pflanzen, 6th edn. Ulmer, Stuttgart

Lawesson JE, Fosaa AM, Olsen E (2003) Calibration of Ellenberg indicator values for Faroe islands. Appl Veg Sci 6:53-62

Lengyel A, Chytrý M, Tichý L (2011) Heterogeneity-constrained random resampling of phytosociological databases. J Veg Sci $22: 175-183$

Lenoir J, Graae BJ, Aarrestad PA, Alsos IG, Armbruster WS et al (2013) Local temperatures inferred from plant communities suggest strong spatial buffering of climate warming across Northern Europe. Global Change Biol 19(5):1470-1481

Lucchese F, Monterosso G (1994) Analysis of beech woods of Simbruini-Ernici mountain range (Central Apennines) using Ellenberg indicators. Ann Bot (Roma) 52:185-202
Möller H (1992) Zur Verwendung des Medians bei Zeigerwertberechnungen nach Ellenberg. Tuexenia 12:25-28

Molinier R (1934) Etudes phytosociologiques et ecologiques en Provence occidentale. Ann Mus Hist Nat, Marseille

Mossa L, Aru A, Fogu MC, Guarino R, Zavattero L (2008) Studio geobotanico del Parco Eolico di Ulassai. Edibo, Catania

Oksanen J, Minchin PR (2002) Continuum theory revisited: what shape are species responses along ecological gradients? Ecol Modell 157:119-129

Oksanen J, Kindt R, O'Hara RB (2009) VEGAN: Community Ecology Package. R package version 1.15-4. http://cc.oulu.fi/ $\sim$ jarioksa/softhelp/vegan.html

Petersen J (2000) Die dünentalvegetation der Wattenmeer-Inseln in der südlichen Nordsee. Husum

Pignatti S (1998) I Boschi d'Italia. UTET, Torino

Pignatti S (1999) La phytosociologie Braun-Blanquetiste et ses perspectives. Coll Phytosoc 27:1-15

Pignatti S, Ellenberg H, Pietrosanti S (1996) Ecograms for phytosociological tables based on Ellenberg's Zeigerwerte. Ann Bot (Roma) 54:5-14

Pignatti S, Bianco PM, Fanelli G, Guarino R, Petersen L, Tescarollo P (2001) Reliability and effectiveness of Ellenberg's indices in checking flora and vegetation changes induced by climatic variations, In: Walter GR, Burga CA, Edwards PJ (eds) Fingerprints of Climate Changes: adapted behaviour and shifting species ranges, New York, London, pp 281-304

Pignatti S, Menegoni P, Pietrosanti S (2005) Bioindicazione attraverso le piante vascolari. Valori di indicazione secondo Ellenberg per le piante della flora d'Italia. Braun Blanquetia 39:1-97

Raimondo FM, Scialabba A, Guarino R, Spallino RE (2013) Genetic diversity in Sicilian populations of Quercus ilex (Fagaceae). Flora Medit 23:245-253

Reger B, Kölling C, Jörg E (2011) Modelling effective thermal climate for mountain forests in the Bavarian Alps: which is the best model? J Veg Sci 22(4):677-687

Rivas-Martìnez S, Fernandez-Gonzalez F, Loidi J (1999) Checklist of plant communities of Iberian Peninsula, Balearic and Canary Islands to suballiance level. Itinera Geobot 13:353-451

Rivas-Martínez S, Fernández-González F, Loidi J, Lousã M, Penas A (2001) Syntaxonomical checklist of vascular plant communities of Spain and Portugal to association level. Itinera Geobot 14:5-341

Roleček J, Tichý L, Zelený D, Chytrý M (2009) Modified TWINSPAN classification in which the hierarchy respects cluster heterogeneity. J Veg Sci 20:596-602

Schaffers AP, Sýkora KV (2000) Reliability of Ellenberg indicator values for moisture, nitrogen and soil reaction: a comparison with field measurements. J Veg Sci 11:225-244

Schröder HK, Andersen HE, Kiehl K (2005) Rejecting the mean: estimating the response of fen plant species to environmental factors by non-linear quantile regression. J Veg Sci 16:373-382

Seidling W, Rohner MS (1993) Zusammenhänge zwischen Reaktions-Zeigerwerten und boden-chemischen Parametern am Beispiel von Waldbodenvegetation. Phytocoenologia 23:301-317

Sicuriello F, De Nicola C, Dowgiallo G, Testi A (2014) Assessing the habitat conservation status by soil parameters and plant ecoindicators. iForest (early view): e1-e8 (online 2014-02-14) URL: http://www.sisef.it/iforest/contents/?id=ifor0963-007

Sokal RR, Rohlf FJ (1995) Biometry: The principles and practice of statistics in biological research, 3rd edn. Freeman, New York

ter Braak CJF, Barendregt LG (1986) Weighted averaging of species indicator values: its efficiency in environ-mental calibration. Math Biosci 78:57-72 
ter Braak CJF, Gremmen NJM (1987) Ecological amplitudes of plant species and the internal consistency of Ellenberg's indicator values for moisture. Vegetatio 69:79-87

ter Braak CJF, Looman CWN (1986) Weighted averaging, logistic regression and the Gaussian response model. Vegetatio 65:3-11

Testi A, Bisceglie S, Guidotti S, Fanelli G (2009) Detecting river environmental quality through plant and macroinvertebrate bioindicators in the Aniene River (central Italy). Aquatic Ecol 43:477-486

Testi A, Fanelli G, Crosti R, Castigliani V, D'Angeli D (2012) Characterizing river habitat quality using plant and animal bioindicators: a case study of Tirino River (Abruzzo Region, Central Italy). Ecol Indic 20:24-33

Thompson K, Hodgson JG, Grime JP, Rorison IH, Band SR, Spencer RE (1993) Ellenberg numbers revisited. Phytocoenologia 23:277-289

Tichý L (2002) JUICE, software for vegetation classification. J Veg Sci 13:451-453

Tichý L, Chytrý M (2006) Statistical determination of diagnostic species for site groups of unequal size. J Veg Sci 17:809-818

Underwood AJ (1997) Experiments in Ecology. Their logical design and interpretation using analysis of variance. Cambridge University Press, Cambridge
Wamelink GWW, Joosten V, van Dobben HF, Berendse F (2000) Reliability of Ellenberg indicator values for moisture, nitrogen and soil reaction: a comparison with field measurements. J Veg Sci 11:225-244

Wamelink GWW, Joosten V, Dobben HF, Berendse F (2002) Validity of Ellenberg indicator values judged from physico-chemical field measurements. J Veg Sci 13:269-278

Wamelink GWW, Goedhart PW, van Dobben HF, Berendse F (2005) Plant species as predictors of soil $\mathrm{pH}$ : replacing expert judgment with measurements. J Veg Sci 16:461-470

Zanella A, Jabiol B, Ponge JF, Sartori G, de Waal R, Van Delft B et al (2011) A European morpho-functional classification of humus forms. Geoderma 164:138-145

Zarzycky K (1984) Indicator values of vascular plants in Poland. Krakow Institut Bot. Polska Akad, Krakow

Zelený D (2014). Use of mean Ellenberg indicator values revisited (again). 23rd EVS-Workshop, Ljubljana 8-12 May 2014: 100

Zelený D, Schaffers AP (2012) Too good to be true: pitfalls of using mean Ellenberg indicator values in vegetation analyses. J Veg Sci 23:419-431 